\title{
The Missing Organizational Dimension of Prisoner Reentry: An Ethnography of the Road to Reentry at a Nonprofit Service Provider
}

\author{
Jonathan J.B. Mijs \\ Harvard University
}

This paper is forthcoming in Sociological Forum 31(2)

An earlier version of this article was presented at the 2014 Annual Meeting of the American Sociological Association in San Francisco. For thoughtful comments, I gratefully acknowledge Anny Fenton, John Halushka, Marieke Liem, Ekédi Mpondo-Dika, Francis Prior, Jasmin Sandelson, Beth Truesdale, participants in the Ethnographic Fieldwork seminar at Harvard University, and Karen Cerulo and the three anonymous reviewers. I thank Jason Beckfield, Matthew Desmond, John Van Maanen, Jocelyn Viterna, Bruce Western, and Christopher Winship for invaluable feedback, guidance, and encouragement. Last but not least, I am indebted to the women and men at Safe without whose candor this research would not have been possible.

Please direct correspondence to Jonathan J.B. Mijs (mijs@ fas.harvard.edu), Harvard University, William James Hall, 33 Kirkland Street, Cambridge, MA 02138. 


\section{ABSTRACT}

Prisoner reentry has received great interest in political sociology, criminology, and beyond. Research documents the struggles of individuals trying to find their way back into society. Less attention has been given to the organizational aspects of reentry. This is unfortunate given the rapid growth of nonprofit reentry organizations in the U.S., which introduces a new set of questions about the context and challenges to prisoner reentry. Drawing on an ethnography of Safe, a nonprofit reentry organization in the Northeast, I describe the organization's pivotal role in institutionalizing the pathway to prisoner reentry: a road to reentry, which takes former prisoners through a process that reconfigures their morality, identity, and social relationships. The road to reentry concept helps bring together scholars of the welfare state and criminology by highlighting how the challenges of prisoner reentry rely on how this process is organized. The way in which prison reentry is organized, in turn, affects former prisoners' agency and shapes the relationship between these men and women and their respective families and communities.

Key words: Prisoner reentry, Organizational Ethnography, Criminology, Welfare State, Structure/Agency 


\section{INTRODUCTION}

The American prison boom has stabilized in recent years, but the jail and prison population of 2,200,000 still stands at a historically unprecedented level (Glaze and Kaeble 2014). A particularly striking fact about mass incarceration is the cycling of prisoners back-andforth between prison and life beyond bars (Travis 2005): in the course of a year, approximately 610,000 men and women are locked up, and 640,000 are released from penitentiary (Carson and Golinelli 2014). A well-established literature in sociology and criminology describes the struggles of former prisoners as they try to find a new place in society (Fader 2013; Glueck and Glueck 1968; Harding, Morenoff, and Herbert 2013; Laub and Sampson 1988; Pager 2003). From this literature we have learned of the hardship faced by those returning from prison (Harding et al. 2014; Western et al. 2015), of barriers to reentry (Petersilia 2003; Travis 2005), and of the importance of 'turning points' such as getting married, having a child, and finding work, which help former prisoners overcome these barriers (Sampson and Laub 1993, 2003).

The extant literature on prisoner reentry unfortunately has less to say about the organizational context in which an increasing number of prisoners make their way back. While the carceral population grew by 35 per cent between 1995 and 2010 and has since stabilized, over that same period the number of government-sponsored nonprofit prisoner reentry organizations increased by 240 per cent (Carson and Golinelli 2014; Miller 2014). The rise of the prisoner reentry organization draws attention to the interplay between former prisoners, the state, and the organization which brings the two together- " full citizenship" (Gottschalk 2014:1). It raises new questions about the context and challenges of prisoner reentry when reentry begets an organizational form. 
This paper sheds light on the new organizational reality of prison reentry based on an ethnography of a reentry organization's discourse and practices. I draw on 12 months of field work at Safe, a government-funded nonprofit reentry contractor annually servicing between 1,300 and 1,600 formerly incarcerated men and women in a Northeastern U.S. city to explore the role in former prisoners' lives played by the nonprofit contractor. I make sense of its position in the nexus between the welfare and the carceral state, and describe the treatment of its 'clients': the men and women making their way back from prison.

I show that in receiving services from a reentry organization, these clients also received their service provider's diagnosis of their problems and a prescription for a course of action- $\mathrm{a}$ road to reentry. It is in establishing this road to reentry, more than in formal service provision, that the reentry organization impacted clients' lives. Despite the valuable knowledge and tools offered through rehabilitative services, the road to reentry put formerly incarcerated persons at risk of dependency (on the organization) and isolation (from their communities), and fostered an inflated sense of agency in the face of the sizeable barriers to finding housing, employment, and entering into new relations, that come with the stigma of criminal conviction.

I conclude by discussing how the road to reentry concept may help bring together scholars of the welfare state and criminology by highlighting how the challenges of prisoner reentry rely on the way in which that process is organized. Specifically, the road to reentry concept adds to turning points in life-course criminology a view on the starting point of prisoner reentry, and the directions it may take from there, given the configuration of that process within the reentry organization. How prison reentry is organized, in turn, affects former prisoners' agency and shapes the relationship between these men and women and their respective families and communities. 
In the following paragraphs I review what we know of prisoner reentry, describe the rise of the reentry organization and discuss its implication for understanding the process through which former prisoners reenter everyday life.

\section{BACKGROUND}

Sociologists and Criminologists on Prisoner Reentry

What awaits a person when he or she is released from penitentiary? Research tells us about the challenges to reentry faced by former prisoners: the difficulties of finding employment (Pager 2003), maintaining social and family ties (Braman 2004), entering into new relations (Lopoo and Western 2005) and returning to the community (Harding et al.2013). Adding to their already vulnerable position, a majority of former prisoners have little education, limited work experience, and suffer from illness and/or struggle with addiction (Greenberg, Dunleavy, and Kutner 2007; Lynch and Sabol 2001; Travis, Solomon, and Waul 2001).

Criminological research on reentry has traditionally focused on how well prison programs prepare prisoners for the challenges of reentry. These are evaluation studies taking the perspective of the practitioner or studies of prison therapy programs from the perspective of the inmate, aimed to assess their effectiveness in bringing about cognitive change (MacKenzie 2006; Stevens 2012). The focus on cognitive change is part and parcel of a body of research in criminology that builds on the tradition of narrative analysis (Ewick and Silbey 1995; McAdams 1993). At the forefront of narrative criminology is Maruna who argues that successful desistance from crime depends on former prisoners making sense of their lives and developing a "coherent and prosocial identity" (Maruna 2001:7). The work of Maruna and others in this tradition 
describes the narratives of change that former prisoners draw on and assesses their predictive power for recidivism (Cid and Martí 2012; Gadd and Farrall 2004; Giordano, Cernkovich, and Rudolph 2002; Veysey, Christian, and Martinez 2009).

The life-course perspective in sociology sheds light on the source(s) of cognitive change, and how such plays out in the lives of former prisoners. It suggests we understand cognitive change as conditioned by major transitions in a person's life-course (Caspi, Bem, and Elder 1989; Elder 1998; Laub and Sampson 1993; Sampson and Laub 2003). Through turning points such as marriage, childbirth, and employment, it is argued, former prisoners find a foothold in everyday life that allows them to successfully desist from crime.

More and more often however former prisoners' return to everyday life is not an individual pursuit, but a process they go through as clients of an organization, such as when they sign up for housing support, job training or other rehabilitative services which governments contract out to nonprofit reentry organizations. We do not know a whole lot about prisoner reentry when it begets an organizational form. This gap in our understanding is particularly problematic because of the dramatic rise of organizational reentry.

\section{The Rise of the Reentry Organization}

Phelps (2013) is the first to my knowledge to rigorously describe the changing rehabilitative treatment of prisoners in the U.S. Addressing the common perception that U.S. penal history has taken a punitive turn in the 1970s, leading away from the rehabilitative ideal, Phelps documents that in fact the type and amount of rehabilitative programs available to prisoners was relatively stable throughout the 1970 s and 80 s. It was not until the 1990s that 
prisons stopped offering educational and vocational programs to the incarcerated population. In the 2000s, the number of academic classes, vocational courses and opportunities for counseling steadily decreased, with one exception: reentry programs, including classes on 'life skills,' 'community readjustment training,' anger management, finance planning, and job application training (Phelps 2013:54). Whereas in 1991, just 15 percent of prisoners had access to reentry programs, by 2004 a quarter of the prison population participated in a reentry program.

[Figure 1 about here]

Accompanying the growth of in-prison reentry program is a dramatic increase in the number of out-of-prison nonprofit reentry organizations: while the growth of the prison population slowed down and eventually came to a halt in 2010 , the number of nonprofit reentry organizations increased by 240 percent, from 390 to 1,340 across the country (Figure 1). In 2013, a total of 840,000 former prisoners were under parole, many of whom received some form of services from a reentry organization (Glaze and Kaeble 2014).

Reentry in the Nexus of the Penal and Welfare State

Scholars of the penal and the welfare state variously describe the coming together of the two as "prisonfare”(Wacquant 2009), “disciplining the poor” (Soss, Fording, and Schram 2011), “penal welfarism” (Garland 2001) or "punishment therapy” (Haney 2010). Despite the different typologies, these scholars fundamentally ask the same twofold question: How do prison and the welfare state interact, and how are citizens impacted by that interaction (Sugie 2012)? 
The growing number of nonprofit reentry organizations in America means that the reentry organization is an increasingly common meeting point of the penal and the welfare state; there where public money meets private efforts. The rise of these organizations is part of a larger trend as nonprofit organization in the U.S. have come to deliver the majority of state-funded direct services to citizens (Marwell 2004; Smith and Lipsky 1993). These developments raise the question, where in the nexus between penal and welfare state, does the reentry organization fit in, and how does its involvement affect the lives of citizens returning from prison?

I empirically address these question with an organizational ethnography of the institution that former prisoners come to rely on as they turn to the reentry organization seeking rehabilitative services, or that they are bound to as a condition of their parole.

\section{A Road to Reentry}

I use the sensitizing concept 'road to reentry' to describe the totality of the organizational discourses and practices intended to rehabilitate the former prisoner. Road is a metaphor that highlights the fact that reentry is understood, by staffers of the organization, and in turn by clients themselves, to be a sequence of steps leading toward a positive end: successful reintegration into social life. There are four elements to the road to reentry concept: (1) it involves a time-horizon and a clearly marked starting point and end result (cf. Mische 2009); (2) progress is associated with advancement on the road to reentry; (3) advancement on the road involves taking pre-defined steps to get there (cf. Giordano et al. 2002:1055); and, (4) the road is bounded on both sides from people, places and things that do not belong there (cf. Leverentz 2010). My use of the concept builds on Tavory and Eliasoph's (2013) conception of 'trajectory,' 
in that it highlights clients' coordination of a particular future-orientation (cf. Mische 2009). The road (to reentry) concept I adopt here however differs from trajectory by the fact that formerly incarcerated persons are directed toward a road that is established not by themselves but by the reentry organization and, indirectly, by the institutional setup of the devolved and decentralized American welfare state (Marwell 2004; Soss et al. 2001).

To turning points, then, the road to reentry perspective adds a view of the starting point from where released prisoners begin their trek. It furthermore shows the direction their path may take, which sometimes leads away from rather than toward turning points, not by accident, but because of its very setup.

\section{DATA AND METHODS}

This study is based on ethnographic research at Safe, a 501(c)3 non-profit, tax-exempt corporation in a Northeastern U.S. city which provides direct support services to persons released from prison. Safe is funded by local, state and federal government, and employs a staff of 35 who see between 1,300 and 1,600 clients annually. About 85 percent of its clients are male, four out of ten are African American, six out of ten are white, a fifth of which is Hispanic. The demographic composition of Safe's clients is virtually identical to that of the national population of released prisoners (Travis et al. 2001:6). In its most recent annual report the organization reports that 56 percent of clients coming in were single, and 29 percent in a relationship (15 percent unknown). Twenty two percent of clients lives with HIV, 23 percent lives with Hepatitis C, and an additional 13 percent lives with HIV and Hepatitis C. Eighty nine percent of Safe clients have a history of drug use. 
Safe is a major hub of government programs, the largest in the state. It provides services through a dozen such programs, ranging from a city-funded program which offers stipend-based job-training to persons coming out of prison to Department of Labor programs and statesponsored substance abuse and health services for formerly incarcerated persons living with an HIV infection. The funds provided by such programs are either channeled through Safe to clients, or pay for Safe staffers to provide counseling, support groups, and individual case management.

Everyone seeking support from Safe is assigned a case manager whom he or she will meet with once a week on average. Anyone eligible for one of the twelve government-funded programs can become a client by going through mandatory orientation, and enrolling in a minimum of two weekly group sessions. Groups are open to participants by referral from their case manager. Participants in groups are expected to attend regularly. Groups vary in length between four and fourteen sessions, and some are open ended.

In addition to its programs, Safe has a common room where clients can spend their day from 8.00 am to $8.30 \mathrm{pm}$, watch television, listen to music, and have access to a phone and to computers. Free lunch is served to Safe clients 4 days a week. The common room has the look and the feel of a spacious living room, with a large-screen television, two couches, and a long table with chairs placed on all four sides. Most of the wall-space is taken up by posters, signs and photographs.

The data for this study were collected in a year of fieldwork at Safe. I spent between 12 to 20 hours a week at the organization for a period of 46 weeks through 2011 and 2012, in addition to six fulltime weeks over the summer. I will be drawing on three types of data in order to combine talk and observation. First and foremost I draw on observations. Spending long days in 
the common room, having coffee, lunch and conversation, has allowed me to hear people's stories and observe conversations and interactions between clients, as well as those between them and staff members. Second I draw on my own participation in weekly mandatory in-take with new clients, group services to clients such as 'life-skills education' and 'emotional management,' and I sat in on therapeutic and peer support groups throughout my research. Third I conducted a series of formal, sit-down, tape-recorded interviews with 20 clients and with the 15 staffers and 5 alumni volunteers who run the group services (alumni are clients who have 'graduated' from the program by having participated in two or more groups for a set period of time).

Formal interview were tape-recorded and transcribed. On other conversations and observations I took field notes on site, which I then expanded from memory, and systematically organized, off site. When in the following pages I present descriptions, these are taken from my field notes. Unless stated otherwise, text in quotes draws directly from my notes or is transcribed from an audio-recording in the case of an interview.

\section{WALKING THE ROAD TO REENTRY}

The Centrality of Choice and Responsibility

It is a hot day and the air conditioning is broken. Eight men and a woman are gathered in a small room that fits a table, a dozen chairs, and little more than that. Bill Williams leads the mandatory one-and-a-half hour long orientation session for recently released prisoners who are new clients at Safe. Bill is a 61 year old African American man, short and sturdily built, with salt-and-pepper hair and beard. As he talks, Bill sits back comfortably in his chair, very much at 
ease. He starts off by summing up some statistics:

One out of three ex-convicts are back in jail six months after their release. We're nine people here, so the statistics say three of us will go back. Six of us will eventually be going back. Those are the numbers, and the numbers are correct. But just because you're sitting here means it doesn't need to be you who goes back to jail. It's all about the choices you make. About going that extra mile. Don't blame anyone else. Don't blame anything.

Orientation each week follows the same pattern. In all the months that I have attended orientation, the only variation has come from the input provided by the men and women who come to the organization seeking welfare services. They sometimes participate actively; interrupt Bill, and volunteer information, while other times Bill has to prompt before he gets a response out of the group. Orientation however is so neatly structured that taking into account this variation, even the interactive part follows a clear pattern. After setting the tone, Bill will go on to illustrate the importance of making what he calls "healthy, productive choices":

Say you walk down the street. Guy bumps into you. Starts cussing and swearing at you. What do you do? [Pause.] You have to be able to say "OK. You got it" and walk away. That's what it takes. Let's say you don't, and you have words. Eventually the police may show up and before you know it you find yourself in the back of their car. Let's take the best case scenario. Say you're booked for violating parole and you go to jail. Maybe a month or two go by, and they release you. No grounds. It wasn't your fault. But 
meanwhile—job's gone. House you be living at? Gone. That's what's at stake. It's all about the choices you make.

Bill's words on the importance of choice are mirrored in the physical make-up of the Safe offices and common room. The first thing one sees when entering the floor is a banner displaying in bright yellow and red on a green background the words "positive change." Posters on walls throughout the building feature information (e.g., on STD prevention) and advice. One such poster, prominently displayed in the common room, states "Life's full of choices, choose carefully." The posters need no decoding; their message is spelled out clearly. The stress on individual choice is a key part of Safe's motto- "reintegration by rehabilitation." It serves to stress the clients' responsibility to choose wisely; to take charge of their lives and to live it responsibly.

All this—advice, parable, display —is part of the organization's road to reentry where progress and change are driven by choice: the choice to be positive, avoid the negative, and to take responsibility for your own future. This emphasis on choice and on individual responsibility taps into a broader logic, e.g. such as widely taught in prison in the Thinking for a Change therapy program: "The idea behind the course is that we can learn to take charge of our livesand lead more productive and more effective lives—-by taking control over the thoughts and feeling that go on inside us" (Bush, Glick, and Taymans 2001). Safe did not make these posters, but borrows from a certain broader set of cultural frames (but not others), and institutes these ideas in its organizational practices. The stress on clients' agency is part of a, perhaps distinctly American, narrative of individual responsibility. The road to reentry I describe here sets out from a basic understanding of agency that supposes full control over one's life, and with that, full 
responsibility.

At various times I witnessed clients at Safe reproducing this narrative. In a conversation I had with Cesar, an alumnus of Safe, he put it as follows: "You gotta crawl before you walk. People complain that there are no jobs, no opportunities, but it's there for you if you want it." I was given a similar account by Joseph, a client, who told me:

The way I'm seeing it, it's all about me. I'm keeping it real. Don't give about the Johns. I'm just going to do the best I can to keep myself together. As long as I'm doing the right thing for me. That might sound a little self-centered, but that too shall pass. I count my blessings and stay prayed up. Stay focused. Nothing in the book says it was going to get easy. Jesus went through a lot too.

One day I walked in on an energetic exchange between two clients, Clint and Joey. The two are standing in the common room, by the window, as Clint is saying, "I'm sick of it. I want to better my life—-be an adult." As he talks he keeps his eyes fixed on Joey, who stands there, his body softly bouncing up and down, like a defending ball player waiting for his opponent to make a move. The moment Clint pauses, Joey picks up where he left it, affirming Clint's words, and adding, "Yeah, take charge of my life; make the right decisions!"

\section{Structural Pasts and Agentic Futures}

Inevitably every man and woman I got to know would tell me the story of how they were incarcerated. Joey told me how he as a middle-child, "kind of left to my own devices," 
developed an addiction to pain killers Percocet and Oxycontin. Joseph told me about how his dad used to beat him up and how that made him violent toward others. With Susan I talked for hours one afternoon about her long history with poor legal representation, incompetent and malign parole officers, and police officers who, in Susan's words, "had it in for me." Some clients would chronologically take me through their childhood, adolescence and up to the day they committed the crime that landed them in jail. Some accounts skipped some steps, or stopped short just before their incarceration. What their stories all have in common is an understanding of the events leading up to their incarceration as minimally involving a number of factors beyond their control: the men and women I talked to felt 'done in' by the criminal justice system, disappointed by their legal defense, or set up to fail by the trauma, neglect, and disadvantages they experienced in their lives, leading up to their incarceration.

When clients told their story to a staffer in orientation, in group, or when a staffer would drop in on my conversation with a client, (s)he would invariably acknowledge the hardships faced by clients. Staffers used the word "disadvantage," or "baggage" to describe the circumstances faced by clients in their past. They would comment, in these conversations, as well as in staff meetings and in interviews with me, on a client's "drug history," "dysfunctional childhood," or "psychological condition."

Interestingly, while the clients' past was understood in terms of a coming to gether of structural forces bearing down on them, the narrative of responsible choices which staffers developed, and which clients took over, pertains exclusively to the future. Analytically, clients' lives are divided into a period to come, an agentic future, that is driven by the choices they make, as distinct from their structural past leading up to their incarceration.

In sum, I have described the organization's road to reentry as based on the idea that by 
making the right choices clients can stay out of jail. This involves a process whereby staffers individualize clients, foster the internalization of moral responsibility, and stress the importance of choice. The choices clients need to make, pertain to finding housing and employment and accepting into their life 'the positive.' The positive becomes tangible mainly by contrast to the negative people, places and things they need to avoid. Beyond real situations, persons and habits, loom a hostile world and a system that is set up against them, while within the walls of the organization clients will find community among peers and professionals. The next section describes how staff members urge clients to make the choice to avoid the negative. Their message, paraphrased, is the following: while you work on yourself, shed the old, and embrace a new community of peers and professionals. What results is a general sense of avoidance that comes to inform a process of reconfiguring relationships which is the complement of the focus on agency and responsibility here described, and the topic of the next section.

\section{Avoiding People, Places and Things}

Brian Purdue is the second-in-command at Safe. He has a serious demeanor: when someone cracks a joke, Brian is rarely the first to laugh. One afternoon, Brian has wheeled his chair into the common room, where the 'emotional management' group convenes. Brian sits at a distance from the chairs and couches where the clients and I are seated. It is a beautiful day out, and Clint, a client, is talking about the weather:

I'm tempted by this weather. I see these guys driving by — all nice jewelries — and, you know, I've some money saved. I look like a bum, but I could look like that. But-I know the end result. Seven months is the longest I've ever been out. 
Brian responds: "Good you brought that up. This is seasonably a tough point for a lot of people. The street lures you in: you want to go out and spend money, but you haven't any." His words are met with nods all around, as well as hums of approval, and an "I hear you" from some of the clients.

Brian goes on to say that they should be extra wary, because, "if you're doing well, holding down a job, keeping off drugs_-people may want you to fall." Again his remark is met with acknowledgement, and some of the clients want to share their experiences. Clint describes how an old friend offered him a drink when he got out of jail and was trying to be sober. In a similar vein, Susan describes a young man in her neighborhood asking her "so, are you ready to relapse again?" She admits: "I wanted to smack that kid in the face." Jill, another client, says she recently met someone she recognized from before she went to jail. The person walked up to her and asked: “Girl, you remember me?" “Of course I do,” Jill replied, “you're part of my nightmare!" Everyone laughs and Brian picks up to talk about distinguishing friends from drugs buddies: "They're the ones who you don't hang with when there's nothing to smoke." Clint admits to having a hard time telling apart a friend from a drug buddy: "I' $m$ twisted, thinking that be my boy."

Through this group meeting and others like it, staffers stress clients' responsibility to carefully choose whom to spend time with, and whom to avoid. As early as in orientation, clients are told that there are negative people and positive people, and that they need to seek out the positive and be wary of the negative-even within the organization. In Bill's words, "I like to think of [the organization] as a family. And like in every family, we have some crooked people here that are no less crooked than the day they went in [to prison]. You need to avoid the 
negative [people] and find the positive [people]." The distinction between negative and positive people mirrors that of the unhealthy and healthy choices clients must evaluate. Staffers make this distinction mainly in terms of the dangers that lure outside, contrasted by the warmth of the community that is the organization. Safe is frequently referred to, by staff members as well as by clients and alumni, as a "community." Clients refer to it as a "safe place," and as "a home." The sense of community is symbolized most strongly -incorporated really-in the common room that is the pulsing heart of the floor on which Safe is housed.

In contrast, the negative is consistently referred to in terms of what staffers call the "people, places and things" that together constitute all the harmful elements of the clients' (criminal) past. These, then, are things that need to be avoided: old habits, familiar places, a bad crowd. As Bill says in orientation:

Let me give you another example. About visiting your old neighborhood; your old friends. Maybe just to show that you're doing fine. Showing off the body works. Good chance you look better now than when you went in [to prison]. So you're visiting the old neighborhood. Just saying Hi. Problem is, you might pull it off [i.e. not get into trouble]. That's when you will go back and do it again. And again. And before you know it, you're into old habits again.

For those clients with a history of using and/or dealing drugs, the neighborhood in particular is considered the geographical root of their problems, to be avoided at all cost. Here and at other points in my fieldwork staffers' words revealed a tension between understanding 
clients as capable and responsible agents, and a conception of the client as a ball — kicked to and fro by malevolent people, or pulled in by the gravitational forces of the defunct neighborhood.

\section{Family Relations}

The community of peers and professionals that Safe tries to be for its clients is juxtaposed to another 'negative' that came up: spouse and family. One day in the emotional management group Michael, a client, described how he was running errands in downtown and suddenly recognized his 16-year old daughter walking on the sidewalk across the street from him. He said he did not know whether to walk over or not, and as he was deliberating what to do, he lost sight of her. Michael's experience came up in staff meeting later that week, when Hank Sullivan, a staffer, described Michael's stance: “He's going slow at that. He's very hesitant to connect to anyone right now. Wants to be in a good place first. He doesn't want to jump into their [his family's] lives." Brian nods approvingly, as do many of the staff members listening, and says: "Sounds good." They leave it at that. That same stance is well captured by Joseph, a client, who one day told me that he sees his children, six year old twin girls, about once every three weeks, which he describes as "a lot," because, as he says, "I need to take care of myself before I can take care of another."

I brought up the issue of family relations in my one-on-one interviews with staff members. The most typical answer I got is verbalized well by Laura Mendez, whom I talked to on her last week at Safe, which inspired a long, reflective, conversation. Laura:

Sometimes people will say, 'oh I want to reconnect with my kids,' right away, and there 
are points where I will encourage the person to really think about how that will affect their other goals. Because reconnecting with people from a long time ago can be emotional and stressful and [it can be good to] have a voice of OK let's think of all the ways that this can affect you before it happens. Some people-I think that their families are really a great support for them in bettering their lives. For some people their family is the opposite. It's something that is a place where trauma has come from; where addiction has come from; where abuse has come from. Or it brings new trauma, stress.

\section{Relational Reconfiguration}

In sum, the organization's road to reentry involves clients making a binary distinction between the positive and the negative. The positive refers to making the right choices. What those choices are exactly is not specified, but a number of things are mentioned that may be considered steps in moving forward on the road to reentry. First, employment is presented as an important and necessary step toward another positive, 'standing on your own feet.' The latter is emphasized more holistically as the focus (on yourself) that is required of clients as they "shed their wicked ways" and learn to do what is right. The third, and most explicit, ingredient to positive action is to avoid the negative. As we have seen, this dogma finds concrete instantiations in those negative people, places and things of the client's past, alongside a less tangible, but no less real, lure of the street and threat of "the system." Stated in slightly exaggerated terms, the message is, "Stay in, avoid the outside."

As such the organization takes clients through a process of relational reconfiguration, where clients' relationships with (old) friends, family and the community they (used to) live in 
are increasingly broken down as they become embedded into a new community of peers and professionals. As a consequence clients come to be increasingly dependent on the organization, which in its structure of activities and setting displays continuity with the correctional institution.

There is a strong appeal to this community for clients who struggle with a lack of structure, having just come out of prison where they learned to surrender control over their own life. The organization's therapeutic logic and its physical manifestation in the common room, provide clients with a clear structure to their lives. The building opens at 8.30 am daily, and lunch is served at $11.30 \mathrm{am}$. The common room is a supervised and regulated space: Bill's office has a window looking out on the common room, and case managers will frequently walk in to pick-up or drop-off clients and linger around. Signs on the walls remind clients of the rules: they may spend a maximum of 10 minutes on the phone; 30 minutes at the computer, and "watching erotic content is strictly forbidden"; clients have to be "awake and alert"-i.e. sober. At $8.30 \mathrm{pm}$ Safe closes for the night.

The more comfortable clients get with the structure imposed on them, and dependent on the services and community that the organization provides, the more they risk becoming isolated from life outside. Staff members acknowledge the problem. I brought up the point in an interview with Samantha, talking about a particular client who I thought was spending a lot of time in the common room.

Samantha: "So, I think the biggest concern, not just for [the client] butfor a lot of people, is as the structures get looser-you know once they are not either on probation or on parole anymore, and not in a halfway house or sober house, when you don't have that structure around you, then the desire to do good becomes a lot harder. And the temptation grows a lot more. And when you don't have all of these rules that you have to follow..." 
At this point her colleague Hank entered the office, and joined our conversation.

Samantha: "It can go on in two ways. What Hank and I always say is, a lot of times, like if you don't see a guy at Safe, like if somebody was doing really well, and they were up here all the time, and then you stop seeing them all of a sudden..."

Hank: "It's a good thing."

Samantha continues: "It's one of two things, right?"

Hank: "Yeah, they're either in trouble, or they're doing very good and they don't have time to hang around the common room, which is good. Which means they can have a life."

Samantha: "Yeah, we want that, like eventually, we want them to leave us, and not spend..."

Hank: "We have guys who've been here for years, and just stay in the common room..."

Samantha: "They haven't progressed...."

Hank: "It's a safe place for them."

Samantha: "They haven't moved forward in their life at all, you know."

Hank: "We want you to be part of this community. But not for eight hours a day when you've been out of jail for five years."

Samantha: "Yeah, it's not healthy for them at all."

\section{CONCLUSION \& DISCUSSION}

The rapid rise of the prison reentry organization means that prison reentry in America more commonly finds an organizational form. This raises a set of questions about what exactly the nonprofit reentry organization is, how its role is best described in the interplay between 
prison and the welfare state, and what the consequences are for former prisoners. The research here presented suggests that the nonprofit reentry service provider in fact deeply intervenes in the moral and social life of its clients, in continuity with the treatment they receive in prison.

With the organization's services comes a set of discourses and practices which aim to restructure the way clients understand themselves and relate to others: parenthood and other social relationships are de-emphasized as clients are taken on an individual(ized) road to reentry, which is institutionalized by the reentry organization. This is quite different from stating that reentry is an individual trajectory. Quite to the contrary, I conclude that the individual experience of reentry can be understood in full only by considering the organizational forces bearing down on the people making their way back from prison. The research presented in this paper suggests that a nonprofit service provider, in name, may add an organizational context to the lives of formerly incarcerated men and women that, in its consequences, bears similarities to the residential reentry programs studied by Haney (2010) and Leverentz (2014).

The origins of reentry programs like the one studied here can be historically traced to $19^{\text {th }}$ century attempts to save (the children of) the poor, and to successive efforts of social reformers to professionalize their occupation by adopting a medical vocabulary of 'curing the criminal pathology' (Katz 1989; Platt 1977). Interventions into family life and protection from the (criminogenic) neighborhood stem from the juvenile system where placement out-of-home and other relational interventions have always been part of the ('treatment') program. This goes back to the establishment of the Juvenile Court in Illinois in 1899 to intervene, cure or to prevent delinquency in youth (Feld 1999). As such, the welfare state's role in the social life of the urban poor has long reach and long roots.

This treatment of clients is testament to the deep-rooted concern that formerly 
incarcerated men and women are not yet ready for, or have not yet earned the right to, participation in everyday life. Mohr's (1994) study of the moral classification of welfare recipients is a case in point. Mohr describes formerly incarcerated persons as treated by welfare providers with 'high moral ambiguity,' as they are deemed to be in a liminal space; eligible for help, but not yet trusted to make their own decisions. For juvenile delinquents the law provides the means for reentry work to take place in a residential program, where formerly incarcerated juveniles are kept away from everyday life (Haney 1996; Inderbitzin 2007).

My study suggests that for adults this same concern finds its expression in a road to reentry that takes formerly incarcerated men and women on a path where they are surrounded by peers and professionals, and shielded-off from negative people, places and things. This process of reconfiguring social relationships is akin to what Burt (2007) calls "network surgery"; the strategic process of breaking off some ties and establishing others - with the important difference that in the present case this process is initiated and supervised not by the client, but by the reentry organization.

\section{Whereto Does the Road to Reentry Lead?}

Studying reentry through the perspective of a road to reentry allows for a clear view on, first, the starting point, direction, and conditions of the reentry process. Second, it highlights the role played by the individuals and organizations that establish, maintain, and supervise the reentry process. The reentry organization I studied embodied and advanced the idea that by making the right choices clients can stay out of jail. The choices clients need to make pertain to finding housing and employment and accepting into their life 'the positive,' which becomes 
tangible mainly by contrast to three negatives they need to avoid: the people, places and things of their past (cf. Leverentz 2010). ${ }^{1}$

The more comfortable clients get with the structure imposed on them, and dependent on the services and community that the organization provides, the more they risk becoming isolated from life outside. In other words, ironically, the more they are 'helped' by the organization, and live up to its expectations, the less comfortable clients may be to venture out and organize their own lives. Consider Maruna (2001:155): "Equally ridiculous is the image of a prison counselor encouraging inmates to "take responsibility for your behavior" while they are kept in an environment that essentially takes all responsibility and choice away from them."

Relational reconfiguration may explain also how, on a larger scale, former prisoners as clients of the welfare state may come to be divorced from their old community (neighborhood, friends and family). It allows us to see the role that the state plays in the ongoing destruction of community life that scholars have argued is the result of mass incarceration (Bobo 2009; Sampson and Loeffler 2010). Staffers' encouraging their clients to 'work on the self' before helping one's family does little to help the plight of the 3 million American children currently growing up without their incarcerated parents (Glaze and Maruschak 2007; Wakefield and Wildeman 2014). Furthermore, a road to reentry that urges avoidance of negative people, places and things may exacerbate the pervasive distrust among the marginalized urban poor (Smith

\footnotetext{
${ }^{1}$ Based on the data I collected I cannot determine to what extent clients first encountered the road of reentry at Safe or if (certain tenets of) it resonated with their experiences, and predates their arrival at the organization. There are strong similarities between Safe's discourse on choice and responsibility and that of other service providers and programs, such as those described by Haney (2010), Leverentz (2014), and Smith (2010). Given the fact that the lives of the urban poor are marked by many organizations (Allard and Small 2013), it is likely that clients are and have been exposed to this discourse at different times and places. All I can show however is the organization's efforts to impress this narrative on its clients, and the clients' receptive responses to these efforts. I thank the reviewer for bringing up this point.
} 
2010) and further erode the very limited social capital these clients have, coming out of prison. This is particularly problematic because social isolation is a strong predictor of housing instability and financial woe (Western et al. 2015:1532).

Agency and Responsibility

The reentry organization that former prisoners rely on may come to shape also their moral lives. In (mandatory) group sessions, clients are encouraged to take control of, and responsibility for, their own lives. Whereas this message may imbue clients with a sense of control that can be helpful in their reentry (Giordano et al. 2002; Maruna 2001), it is an ambivalent sense for at the same time staff members constantly remind clients of how little control they have over others and of their social environment more generally. ${ }^{2}$ This is most clear when staffers urge clients to stay away from the streets, for they lure them toward the negative. As clients learn to take control, they also internalize responsibility. The organization urges them to do so in the face of real challenges to reentry which add to their already vulnerable position, as most suffer from illness and/or struggle with addiction, and have very limited education and work experience to build on.

These factors are accepted and recognized as structural disadvantages when staffers talk about the factors leading to clients' incarceration. Looking to the future however, these factors are ignored by staffers, who impress on clients a notion of control and responsibility for their own actions. In short, clients' lives are understood by staffers to have a structural past, and an

\footnotetext{
${ }^{2}$ As Giordano et al. (2002:1026) argue, perhaps "the real play of agency is in the middle" of the "continuum of advantage to disadvantage"; that is, a call on client's agency may be an effective strategy for some clients, but to the detriment of those whose lives are more dramatically marked by structural disadvantages.
} 
agentic future, which will be built on the choices they make. The organization's discourse on responsibility leaves little room for a consideration of the structural forces of poverty, disrupted families, and a hostile labor market, that continue to shape clients' lives. Maruna argues that, "to desist from crime, ex-offenders need to develop a coherent, prosocial identity for themselves. As such they need to account for and understand their criminal pasts (why they did what they did), and they also need to understand why they are now "not like that anymore" (Maruna 2001:8). By divorcing clients' (structural) pasts from their (agentic) future, the organization complicates the development of a coherent self-understanding.

The stress on clients' agency is fueled by a broader narrative of individual responsibility that shifts responsibility of failure and success to clients and away from the organization on whose help they rely (Leverentz 2014:180). Compare to Desmond (2008) who documents how the U.S. Forest Service impresses on firefighters an institutional logic of individual responsibility, blaming death on the fire line on individual mistakes, never on organizational error. Clients' internalization of responsibility for their reentry is particularly worrisome in light of the statistic that only one third of released prisoners successfully stays out (Cooper, Durose, and Snyder 2014).

Underlying many of the issues here described is the question: who are the clients of the reentry organization (see Castellano 2011)? Rehabilitative services are meant to directly assist the formerly incarcerated men and women, but the organization's mission, more broadly, is to make for safer communities - a concern that underlies much of the programming. Whereas in the ideal case, helping rehabilitate clients leads to safer communities, in practice the clients' and the community's interest do not always coincide. Such is the case when clients are (perceived to be) a burden to their families, a negative influence on their children, and a danger to the 
neighborhood.

\section{Implications}

Given the issues raised in this paper, perhaps reentry organizations such as Safe cannot expect to play an unambiguously positive role in rehabilitation, but should more realistically focus on giving these vulnerable men and women the immediate tools they need to lead dignified lives: housing, mobility, and medical care-without rather than within the context of an organizational community.

If the goal of prisoner reentry is social integration, then the question is how strong a basis for attachment and social support these men and women can realistically expect to build (Cullen 1994; Western et al. 2015) if their social interactions are confined to peers, professionals and colleagues at the precarious (day) labor that they are most likely to find in their search for employment (Kalleberg 2009; Purser 2006). The call to avoid community life keeps clients from an important turning point distinguished in the life-course literature: the degree to which a person is rooted in family, social and community life (Sampson and Laub 1990). Notwithstanding the positive effects associated with neighborhood change (Kirk 2009, 2012), staying away from family and (old) friends, does little to address and repair "emotional and stressful" relationships (quoting a Safe staffer) (cf. Maruna and Roy 2007:117), and keeps clients from the beneficial role that familiar faces may play in their lives (Travis 2005; Visher et al. 2004). ${ }^{3}$

\footnotetext{
${ }^{3}$ Whereas research suggests that the risks of romantic relationships may outweigh its potential benefits for formerly incarcerated men and women (Braman 2004; Leverentz 2011; Wyse, Harding, and Morenoff 2014), studies also describe how family ties more generally, e.g. with parents, siblings, aunts and cousins, can be and often are important sources of social support (Leverentz 2011; Martinez and Christian 2008; Schroeder, Giordano, and Cernkovich 2010;
} 
An alternative road to reentry is one that takes clients through rather than around their communities. As argued above, the organization's efforts to individualize its clients in order to make them independent, may paradoxically lead to foster dependency on the organization. A more fruitful approach is to go beyond the binary of in/dependence to recognize and aim for a relationship of interdependence between the reentry organization, the client and his or her community. The key, then, is to look for ways in which clients can, while relying on the organization to help out where it can (e.g. in finding work, housing, and substance abuse treatment), be there for others: their immediate dependents, family and friends, and their communities, more generally. For providing support can be a great source of self-worth and respect (Cullen 1994; Maruna and Roy 2007) which can more realistically lead to their empowerment than a 'focus on the self,' that offers no other way to self-respect than precarious work, and which fosters self-blame for failing to overcome the barriers that these men and women, unfortunately, are more likely than not to meet on their path.

Western et al. 2015). 


\section{REFERENCES}

Allard, Scott W. and Mario L. Small. 2013. "Reconsidering the Urban Disadvantaged The Role of Systems, Institutions, and Organizations." The ANNALS of the American Academy of Political and Social Science 647(1):6-20.

Bobo, Lawrence D. 2009. “Crime, Urban Poverty, and Social Science.” Du Bois Review: Social Science Research on Race 6(02):273-78.

Braman, Donald. 2004. Doing Time on the Outside: Incarceration and Family Life in Urban America. Ann Arbor, MI: University of Michigan Press.

Burt, Ronald S. 2007. Brokerage and Closure: An Introduction to Social Capital. New York: Oxford University Press.

Bush, Jack, Barry Glick, and Juliana Taymans. 2001. Thinking for a Change: Integrated Cognitive Behavior Change Program. Washington, D.C.: National Institute of Corrections.

Carson, E. Ann and Daniela Golinelli. 2014. Prisoners in 2012. Trends in Admissions and Releases, 1991-2012. Washington, D.C.: Bureau of Justice Statistics.

Caspi, Avshalom, Daryl J. Bem, and Glen H. Elder. 1989. "Continuities and Consequences of Interactional Styles Across the Life Course.” Journal of Personality 57(2):375-406.

Castellano, Ursula. 2011. “Courting Compliance: Case Managers as 'Double Agents' in the Mental Health Court.” Law \& Social Inquiry 36(2):484-514.

Cid, José and Joel Martí. 2012. "Turning Points and Returning Points: Understanding the Role of Family Ties in the Process of Desistance.” European Journal of Criminology 9(6):60320. 
Cooper, Alexia D., Matthew R. Durose, and Howard N. Snyder. 2014. Recidivism of Prisoners Released in 30 States in 2005: Patterns From 2005 to 2010. Washington, D.C.: Bureau of Justice Statistics.

Cullen, Francis T. 1994. "Social Support as an Organizing Concept for Criminology: Presidential Address to the Academy of Criminal Justice Sciences.” Justice Quarterly 11:527.

Desmond, Matthew. 2008. On the Fireline: Living and Dying with Wildland Firefighters. Chicago, IL: University of Chicago Press.

Elder, Glen H. 1998. “The Life Course as Developmental Theory.” Child Development 69(1):112.

Ewick, Patricia and Susan S. Silbey. 1995. "Subversive Stories and Hegemonic Tales: Toward a Sociology of Narrative.” Law \& Society Review 29(2):197-226.

Fader, Jamie J. 2013. Falling Back: Incarceration and Transitions to Adulthood among Urban Youth. New Brunswick, NJ: Rutgers University Press.

Feld, Barry C. 1999. Bad Kids: Race and the Transformation of the Juvenile Court. London: Oxford University Press.

Gadd, David and Stephen Farrall. 2004. "Criminal Careers, Desistance and Subjectivity Interpreting Men's Narratives of Change.” Theoretical Criminology 8(2):123-56.

Garland, David. 2001. The Culture of Control: Crime and Social Order in Contemporary Society. Chicago, IL: University of Chicago Press.

Giordano, Peggy C., A. Cernkovich, and Jennifer L. Rudolph. 2002. "Gender, Crime, and Desistance: Toward a Theory of Cognitive Transformation.” American Journal of Sociology 107(4):990-1064. 
Glaze, Lauren E. and Danielle Kaeble. 2014. Correctional Populations in the United States, 2013. Washington, D.C.: Bureau of Justice Statistics.

Glaze, Lauren E. and Laura M. Maruschak. 2007. Parents In Prison And Their Minor Children. Washington, D.C.: U.S. Department of Justice.

Glueck, Sheldon and Eleanor T. Glueck. 1968. Delinquents and Nondelinquents in Perspective. Cambridge, MA: Harvard University Press.

Gottschalk, Marie. 2014. Caught: The Prison State and the Lockdown of American Politics. Princeton, NJ: Princeton University Press.

Greenberg, E., E. Dunleavy, and M. Kutner. 2007. Literacy Behind Bars: Results from the 2003 National Assessment of Adult Literacy Prison Survey (NCES 2007-273). Washington, D.C.: National Center for Education Statistics.

Haney, Lynne. 1996. "Homeboys, Babies, Men in Suits: The State and the Reproduction of Male Dominance." American Sociological Review 61(5):759-78.

Haney, Lynne A. 2010. Offending Women. Power, Punishment, and the Regulation of Desire. Berkeley, CA: University of California Press.

Harding, David J., Jeffrey D. Morenoff, and Claire W. Herbert. 2013. "Home Is Hard to Find Neighborhoods, Institutions, and the Residential Trajectories of Returning Prisoners." The ANNALS of the American Academy of Political and Social Science 647(1):214-36.

Harding, David J., Jessica J. B. Wyse, Cheyney Dobson, and Jeffrey D. Morenoff. 2014. “Making Ends Meet After Prison.” Journal of Policy Analysis and Management 33(2):440-70. 
Inderbitzin, Michelle. 2007. "Inside a Maximum-Security Juvenile Training School Institutional Attempts to Redefine the American Dream and 'normalize’ Incarcerated Youth.” Punishment \& Society 9(3):235-51.

Kalleberg, Arne L. 2009. "Precarious Work, Insecure Workers: Employment Relations in Transition." American Sociological Review 74(1):1-22.

Katz, Michael B. 1989. The Undeserving Poor: From the War on Poverty to the War on Welfare. New York: Pantheon Books.

Kirk, David S. 2009. “A Natural Experiment on Residential Change and Recidivism: Lessons from Hurricane Katrina.” American Sociological Review 74(3):484-505.

Kirk, David S. 2012. "Residential Change as a Turning Point in the Life Course of Crime: Desistance or Temporary Cessation?” Criminology 50(2):329-58.

Laub, John H. and Robert J. Sampson. 1988. "Unraveling Families and Delinquency: A Reanalysis of the Gluecks' Data." Criminology 26(3):355-80.

Laub, John H. and Robert J. Sampson. 1993. "Turning Points in the Life Course: Why Change Matters to the Study of Crime." Criminology 31(3):301-25.

Leverentz, Andrea. 2010. "People, Places, and Things: How Female Ex-Prisoners Negotiate Their Neighborhood Context." Journal of Contemporary Ethnography 39(6):646-81.

Leverentz, Andrea. 2011. "Being a Good Daughter and Sister: Families of Origin in the Reentry of African American Female Ex-Prisoners.” Feminist Criminology 6(4):239-67.

Leverentz, Andrea M. 2014. The Ex-Prisoner's Dilemma: How Women Negotiate Competing Narratives of Reentry and Desistance. New Brunswick, NJ: Rutgers University Press. Lopoo, Leonard M. and Bruce Western. 2005. "Incarceration and the Formation and Stability of Marital Unions.” Journal of Marriage and Family 67(3):721-34. 
Lynch, James P. and William J. Sabol. 2001. Prisoner Reentry in Perspective. Washington, D.C.: Urban Institute.

MacKenzie, Doris Layton. 2006. What Works in Corrections. Reducing the Criminal Activities of Offenders and Deliquents. Cambridge: Cambridge University Press.

Martinez, Damian J. and Johnna Christian. 2008. “The Familial Relationships of Former Prisoners: Examining the Link between Residence and Informal Support Mechanisms." Journal of Contemporary Ethnography 38(2):201-24.

Maruna, Shadd. 2001. Making Good: How Ex-Convicts Reform and Rebuild Their Lives. Washington, D.C.: American Psychological Association.

Maruna, Shadd and Kevin Roy. 2007. "Amputation or Reconstruction? Notes on the Concept of 'Knifing Off' and Desistance From Crime.” Journal of Contemporary Criminal Justice 23(1):104-24.

Marwell, Nicole P. 2004. "Privatizing the Welfare State: Nonprofit Community-Based Organizations as Political Actors.” American Sociological Review 69(2):265-91.

McAdams, Dan P. 1993. The Stories We Live by: Personal Myths and the Making of the Self. New York: Guilford Press.

Miller, Reuben Jonathan. 2014. "Devolving the Carceral State: Race, Prisoner Reentry, and the Micro-Politics of Urban Poverty Management.” Punishment \& Society 16(3):305-35.

Mische, Ann. 2009. "Projects and Possibilities: Researching Futures in Action.” Sociological Forum 24(3):694-704.

Mohr, John W. 1994. "Soldiers, Mothers, Tramps and Others: Discourse Roles in the 1907 New York City Charity Directory." Poetics 22(4):327-57. 
Pager, Devah. 2003. “The Mark of a Criminal Record.” American Journal of Sociology 108(5):937-75.

Petersilia, Joan. 2003. When Prisoners Come Home: Parole and Prisoner Reentry. London: Oxford University Press.

Phelps, Michelle S. 2013. "The Paradox of Probation: Community Supervision in the Age of Mass Incarceration." Law \& Policy 35(1-2):51-80.

Platt, Anthony M. 1977. The Child Savers: The Invention of Delinquency. Chicago, IL: University of Chicago Press.

Purser, Gretchen. 2006. Waiting for Work: An Ethnography of a Day Labor Agency. Institute for the Study of Social Change, ISSC Fellows Working Papers, eRepository, California Digital Library.

Sampson, Robert J. and John H. Laub. 1990. "Crime and Deviance over the Life Course: The Salience of Adult Social Bonds.” American Sociological Review 55(5):609-27.

Sampson, Robert J. and John H. Laub. 1993. Crime in the Making: Pathways and Turning Points Through Life. Cambridge, MA: Harvard University Press.

Sampson, Robert J. and John H. Laub. 2003. Shared Beginnings, Divergent Lives: Delinquent Boys to Age Seventy. Cambridge, MA: Harvard University Press.

Sampson, Robert J. and Charles Loeffler. 2010. "Punishment's Place: The Local Concentration of Mass Incarceration.” Daedalus 139(3):20-31.

Schroeder, Ryan D., Peggy C. Giordano, and Stephen A. Cernkovich. 2010. "Adult Child-Parent Bonds and Life Course Criminality.” Journal of Criminal Justice 38(4):562-71.

Smith, Sandra Susan. 2010. Lone Pursuit: Distrust and Defensive Individualism Among the Black Poor. New York: Russell Sage Foundation. 
Smith, Steven Rathgeb and Michael Lipsky. 1993. Nonprofits for Hire. The Welfare State in the Age of Contractin. Cambridge, MA: Harvard University Press.

Soss, Joe, Richard C. Fording, and Sanford F. Schram. 2011. Disciplining the Poor. Neoliberal Paternalism and the Persistent Power of Race. Chicago, IL: University of Chicago Press.

Soss, Joe, Sanford F. Schram, Thomas P. Vartanian, and Erin O'Brien. 2001. “Setting the Terms of Relief: Explaining State Policy Choices in the Devolution Revolution.” American Journal of Political Science 45(2):378-95.

Stevens, Alisa. 2012. “'I Am the Person Now I Was Always Meant to Be': Identity Reconstruction and Narrative Reframing in Therapeutic Community Prisons.” Criminology and Criminal Justice 12(5):527-47.

Sugie, Naomi F. 2012. "Punishment and Welfare: Paternal Incarceration and Families' Receipt of Public Assistance." Social Forces 90(4):1403-27.

Tavory, Iddo and Nina Eliasoph. 2013. "Coordinating Futures: Toward a Theory of Anticipation.” American Journal of Sociology 118(4):908-42.

Travis, Jeremy. 2005. But They All Come Back: Facing the Challenges of Prisoner Reentry. Washington, D.C.: The Urban Institute.

Travis, Jeremy, Amy L. Solomon, and Michelle Waul. 2001. From Prison to Home: The Dimensions and Consequences of Prisoner Reentry. Washington, D.C.: The Urban Institute.

Veysey, Bonita, Johnna Christian, and Damian J. Martinez. 2009. How Offenders Transform Their Lives. Cullompton: Willan. 
Visher, Christy, Vera Kachnowski, Nancy La Vigne, and Jeremy Travis. 2004. Returning Home: Understanding the Challenges of Prisoner Reentry. Maryland Pilot Study: Findings from Baltimore. Washington, D.C.: Urban Institute.

Wacquant, Loic. 2009. Punishing the Poor: The Neoliberal Government of Social Insecurity. Durham, NC: Duke University Press.

Wakefield, Sara and Christopher Wildeman. 2014. Children of the Prison Boom: Mass Incarceration and the Future of American Inequality. London: Oxford University Press.

Western, Bruce, Anthony A. Braga, Jaclyn Davis, and Catherine Sirois. 2015. "Stress and Hardship after Prison.” American Journal of Sociology 120(5):1512-47.

Wyse, Jessica J. B., David J. Harding, and Jeffrey D. Morenoff. 2014. "Romantic Relationships and Criminal Desistance: Pathways and Processes.” Sociological Forum 29(2):365-85. 
Figure 1. Growth of the parole population and the number of reentry organizations

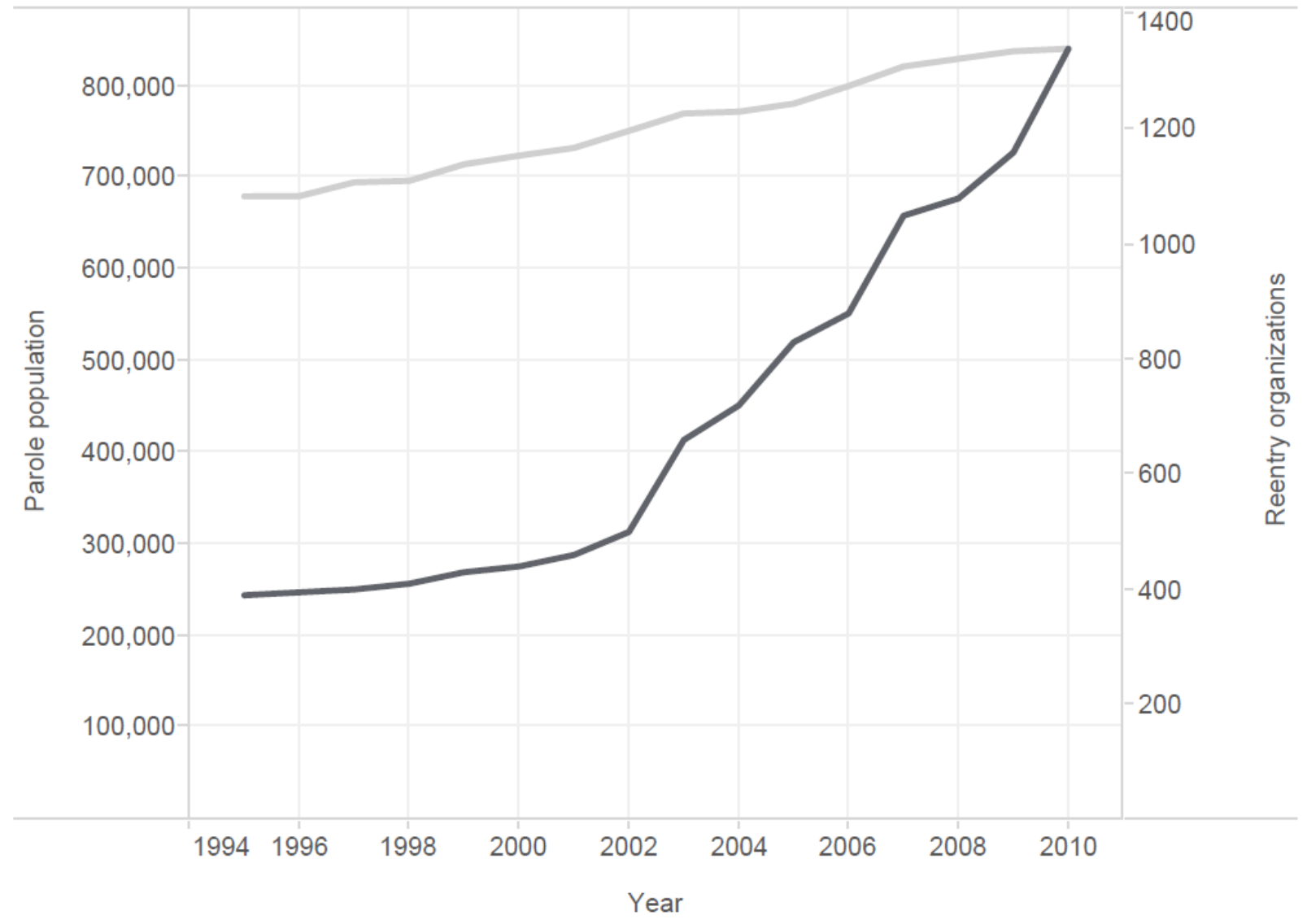

Note. The size of the parole population is indicated by the scale on the left side of the graph and plotted in grey, the number of reentry organizations is indicated by the scale on the right and plotted in black. Source: Carson and Golinelli 2014; Miller 2014. 